\title{
Pengembangan Aplikasi Pencatatan Pengeluaran Kas Berbasis Web Menggunakan Framework Codeigniter (Studi Kasus : Nusantara HPL)
}

\author{
Tri Ramdhany ${ }^{1}$, Liesna Hardianti ${ }^{2}$ \\ ${ }^{1,2}$ Program Studi Sistem Informasi
}

${ }^{1,2}$ STMIK LPKIA Bandung Jl. Soekarno Hatta No. 456 Bandung, Jawa Barat Email : triramdhany@gmail.com¹,170213003@fellow.lpkia.ac.id ${ }^{2}$

\begin{abstract}
ABSTRAK
Nusantara HPL bergerak dalam bidang perdagangan bahan furniture interior serta jasa kontraktor sipil, interior dan advertising logo. Dalam memenuhi kebutuhan informasinya mengalami beberapa kendala seperti sulitnya melakukan pencarian data serta pengolahan data pengeluaran untuk menyajikan laporan selain itu sulitnya dalam melakukan rekapitulasi terhadap pengeluarkan yang terjadi ditambah data yang digunakan secara bersama oleh bagian bagian yang terlibat menyebabkan adanya saling menunggu dalam menyelesaikan pekerjaan pencatatan pengeluaran kas.

Berdasarkan permasalahan tersebut maka perlu dibangun sebuah aplikasi berbasis web, untuk memudahkan pengembangan aplikasi digunakan framework Codeinater dengan pendekatan pengembangan aplikasi secara prototype agar kebutuhan dari pengguna terakomodir dan dikarenakan metode prototype memiliki iterasi lebih pendek maka pengembangan aplikasi lebih cepat selesai.

Dengan adanya aplikasi berbasis web maka aktivitas pencatatan pengeluaran kas dapat dilakukan secara pararel di bagian yang saling terkait sehingga pembuatan laporan pengeluaran kas menjadi lebuih cepat dan dengan adanya fitur pencarian di aplikasi tersebut memudahkan pengguna dalam melakukan pencarian data pengeluaran kas.
\end{abstract}

Kata Kunci: Pengeluaran Kas, Codeigniter, Website, Biaya Operasional

\section{ABSTRACT}

Nusantara HPL is engaged in trading interior furniture materials as well as civil contracting services, interior and advertising logos. In fulfilling the information needs, there are several obstacles such as the difficulty of searching for data and processing expenditure data to present reports besides the difficulty in recapitulating the issuance that occurs plus the data that is used jointly by the parts involved causing the waiting to complete the recording work. cash disbursements.

Based on these problems, it is necessary to build a web-based application, to facilitate application development the Codeignater framework is used with a prototype application development approach so that the needs of users are accommodated and because the prototype method has shorter iterations, application development is completed more quickly.

With the existence of a webbased application, the recording of cash disbursements can be carried out in parallel in interrelated sections so that the making of cash disbursement reports becomes faster and the search feature in the application makes it easier for users to search for cash outflow data.

Keywords: Cash Expenditures, Codeigniter, Website, Operational Costs 


\section{PENDAHULUAN}

Di era modern saat ini, informasi sangat dibutuhkan oleh berbagai pihak. Bahkan teknologi informasi saat ini berkembang dengan cepat sehingga perusahaan mulai merasakan bahwa teknologi informasi perlu digunakan untuk meningkatkan penyediaan informasi agar dapat mendukung proses pengambilan keputusan serta evaluasi kinerja perusahaan.

Untuk mengimbangi perkembangan industri saat ini, Nusantara HPL memanfaatkan penggunaan teknologi dalam memenuhi kebutuhan informasi yang dibutuhkannya. Nusantara HPL sudah mempunyai sistem untuk menunjang kegiatan penjualan tunainya namun dalam proses pencatatan pengeluaran kas masih dilakukan secara manual yaitu dengan mencatatnya di buku.

Nusantara HPL memerlukan sebuah sistem untuk mengelola proses pencatatan pengeluaran kas secara efektif dan efisien untuk meminimalisir biaya yang harus dikeluarkan seperti biaya pembelian alat tulis kantor serta laporan yang dihasilkannya pun akan lebih akurat, cepat, dan mudah dalam mendapatkannya.

\subsection{Identifikasi Masalah}

Sesuai dengan apa yang dipaparkan dalam pendahuluan maka dapat di indentifikasi bahwa dalam aktivitas pencatatan pengeluaran kas terdapat kendala-kendala yang terjadi seperti sulitnya dalam membuat rekapitulasi pengeluaran kas dikarenakan data yang dikelola banyak dan digunakan oleh beberapa bagian yang terlibat. Sehingga hal ini pula menyebabkan keterlambatan dalam pembuatan laporan pengeluaran kas.

Permasalah pun muncul ketika pengguna mencari data pengeluarkan kas yang di butuhkan secara cepat hal ini disebab penyimpanan data masih berupa arsip fisik, sehingga dengan jumlah data yang tersimpan sangat menyulitkan jika mencari data secara cepat.

\subsection{Hasil Penelitian}

Dengan dibangunnya aplikasi berbasis website maka proses pencatatan pengeluaran kan dapat dilakukan secara pararel oleh bagian yang terlibat sehingga rekapitulasi dan pembuatan laporan pengeluaran kan dapat dibuat secara cepat dan dapat diakses dengan mudah oleh para pengguna. 
Selain itu dengan adanya fitur pencarian memudahkan pengguna dalam mencari data pengeluarn kas yang dibutuhkan ketika diperlukan sehingga tidak menghambat pekerjaan lain yang bergantung pada data tersebut.

\section{LANDASAN TEORI}

\subsection{Pengeluaran Kas Biaya Operasional}

Menurut (Ningroom, F. K., Husaini, A. \& Azizah, 2013)yang mengutip pernyataan Mulyadi, menyatakan bahwa sistem akuntansi pengeluaran kas adalah "suatu catatan yang dibuat untuk melaksanakan kegiatan pengeluaran baik dengan cek maupun dengan uang tunai yang digunakan untuk kegiatan umum perusahaan.”

Menurut (Wisesa et al., 2014) mengutip pernyataan Jopie Jusuf mengenai pengertian biaya operasional bahwa biaya operasional atau biaya operasi adalah biayabiaya yang tidak berhubungan langsung dengan produk perusahaan tetapi berkaitan dengan aktivitas operasional perusahaan sehari-hari. Adapun indikator biaya operasional dijelaskan oleh Menurut (Muria, 2018) yang mengutip pernyataan Sofyan Syafri Harahap mengenai indikator biaya operasional menyatakan bahwa terdapat dua indikator terkait hal itu yaitu sebagai berikut:

1. Biaya penjualan, adalah seluruh biaya-biaya yang dikeluarkan untuk kegiatan penjualan sampai barang itu berada di tangan konsumen, seperti biaya pengiriman, pajak-pajak yang berkenaan dengan penjualan, promosi, dan gaji tenaga penjual.

2. Biaya umum dan administrasi, adalah biaya yang dikeluarkan untuk kegiatankegiatan di luar kegiatan penjualan seperti kegiatan administrasi, kegiatan personalia, dan umum. Misalnya gaji pegawai bagian umum (yang bukan barang produksi, pemasaran), air, telepon, pajak, iuran, dan biaya kantor.

\subsection{Codeigniter}

Menurut (Cahyati \& Murti, 2018) yang mengutip pernyataan Septian Gungun mengenai pengertian Codeigniter menyatakan bahwa Codeigniter adalah aplikasi open source yang berupa framework dengan model MVC (Model, View, Controller) untuk membangun website dinamis. 
Framework secara sederhana dapat diartikan kumpulan dari fungsifungsi/prosedur-prosedur dan class-class untuk tujuan tertentu yang sudah siap digunakan sehingga bisa lebih mempermudah dan mempercepat pekerjaan seorang pemrograman, tanpa harus membuat fungsi atau class dari awal. (Supono \& Putratama, $2016: 109)$

Menurut (Supono \& Putratama, 2016), Model View Controller merupakan suatu konsep dalam pembangunan aplikasi web yang memisahkan pengembangan aplikasi berdasarkan komponen utama yang membangun sebuah aplikasi seperti manipulasi data, user interface, dan bagian yang menjadi kontrol aplikasi.

Terdapat tiga komponen yang membangun suatu MVC pattern dalam suatu aplikasi, yaitu:

1. View, merupakan bagian yang menangani presentation logic. Pada suatu aplikasi web bagian ini biasanya berupa file template HTML, yang diatur oleh controller. View berfungsi untuk menerima dan merepresentasikan data kepada user. Bagian ini tidak memiliki akses langsung terhadap bagian model.

2. Model, biasanya berhubungan langsung dengan database untuk memanipulasi data (insert, update, delete, search), menangani validasi dari bagian controller, namun tidak dapat berhubungan langsung dengan bagian view.

3. Controller, merupakan bagian yang mengatur hubungan antara bagian model dan bagian view, controller berfungsi untuk menerima request dan data dari user kemudian menentukan apa yang akan diproses oleh aplikasi.

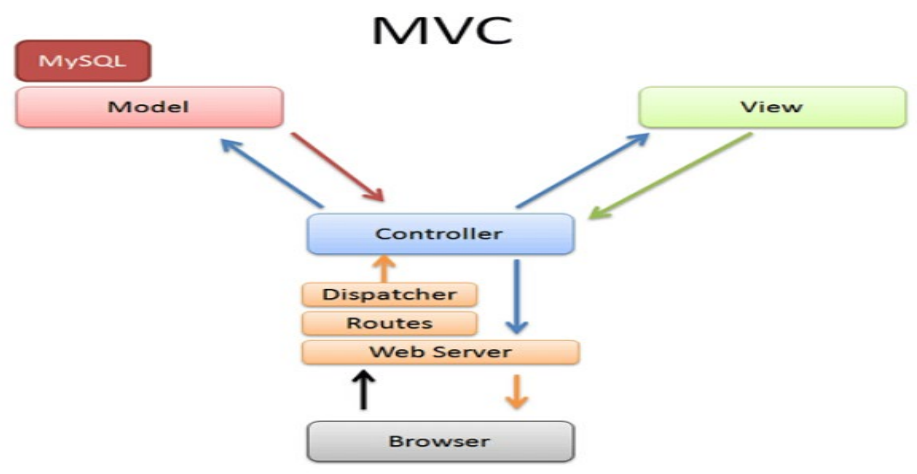

Gambar 1: Cara Kerja MVC

Sumber : (Supono \& Putratama, 2016 : 111) 


\section{ANALISIS PERANCANGAN}

\subsection{Identifikasi Proses Bisnis}

Berikut ini merupakan uraian tekstual proses pengeluaran kas atas pembiayaan operasional pada Nusantara HPL:

1. Staff Admin akan menerima Permintaan Pengeluaran Kas (PPK) dari Direktur II lalu Staff Admin akan membuat Bukti Pengeluaran Kas (BPK) sebanyak 2 (dua) rangkap dan akan diserahkan kepada Direktur II sebagai permintaan persetujuan untuk mengeluarkan uang dalam rangka melakukan pembayaran terhadap pembiayaan-pembiayaan yang harus dilakukan sedangkan PPK yang diterima akan diarsipkan oleh Staff Admin.

2. Setelah mendapatkan persetujuan dari Direktur II maka selanjutnya Staff Admin akan mengeluarkan uang baik secara tunai maupun transfer bank sejumlah yang tertera pada Bukti Pengeluaran Kas (BPK) yang telah disetujui. Lalu Staf Admin akan menyerahkan 1 (satu) lembar BPK kepada Staf Akuntansi dan 1 (satu) lembar sisanya akan diarsipkan oleh Staff Admin.

3. Setelah dilakukan pembayaran, Staff Admin akan menerima kwitansi sebagai bukti telah dilakukannya proses pembayaran lalu kwitansi tersebut akan segera diserahkan kepada Staff Akuntansi.

4. Staff Akuntansi akan menerima kwitansi dan Bukti Pengeluaran Kas (BPK) yang diserahkan oleh Staff Admin, selanjutnya Staff Akuntansi akan mencatat transaksi pengeluaran kas yang terjadi berdasarkan kedua dokumen tersebut di Buku Catatan Harian Kas (BHK) dan akan mengarsipkan kwitansi dan BPK tersebut.

5. Pada akhir bulan, Staff Akuntansi akan merekapitulasi pengeluaran pada bulan tersebut berdasarkan catatan pada Buku Catatan Harian Kas (BHK) dan membuat laporannya yang kemudian akan diserahkan kepada Direktur II dan Direktur Utama.

Berikut ini merupakan pemetaan proses bisnis pengeluaran kas atas pembiayaan operasional pada Nusantara HPL: 


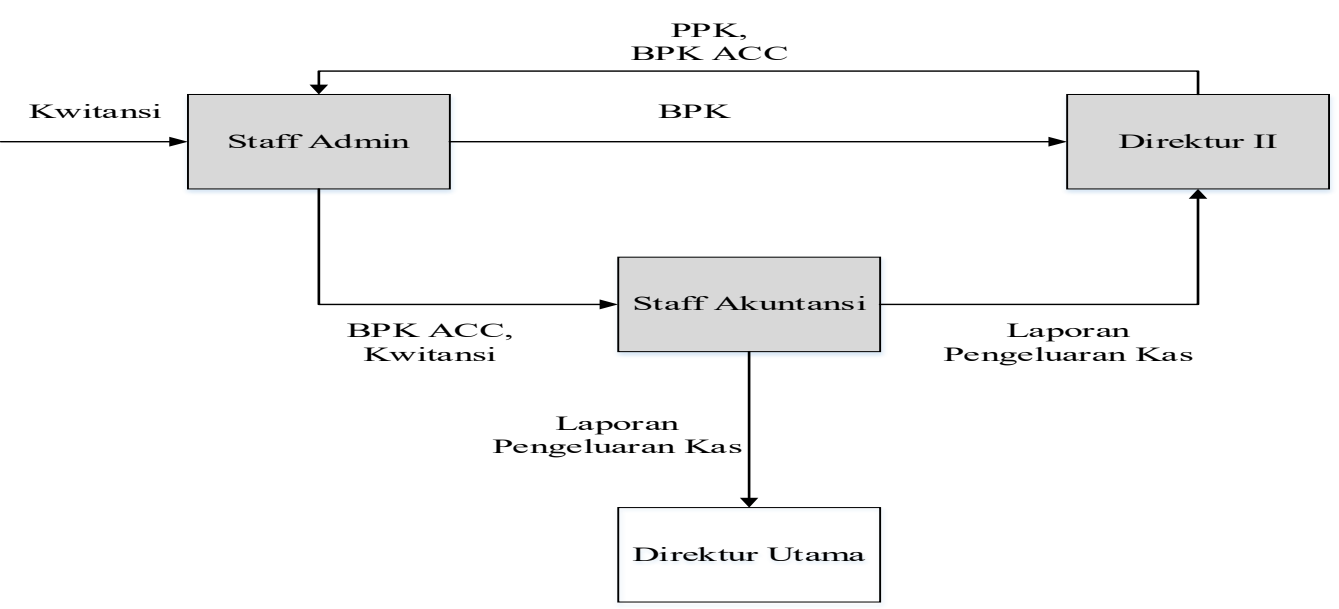

Gambar 2: Pemetaan proses bisnis yang berjalan pada Nusantara HPL

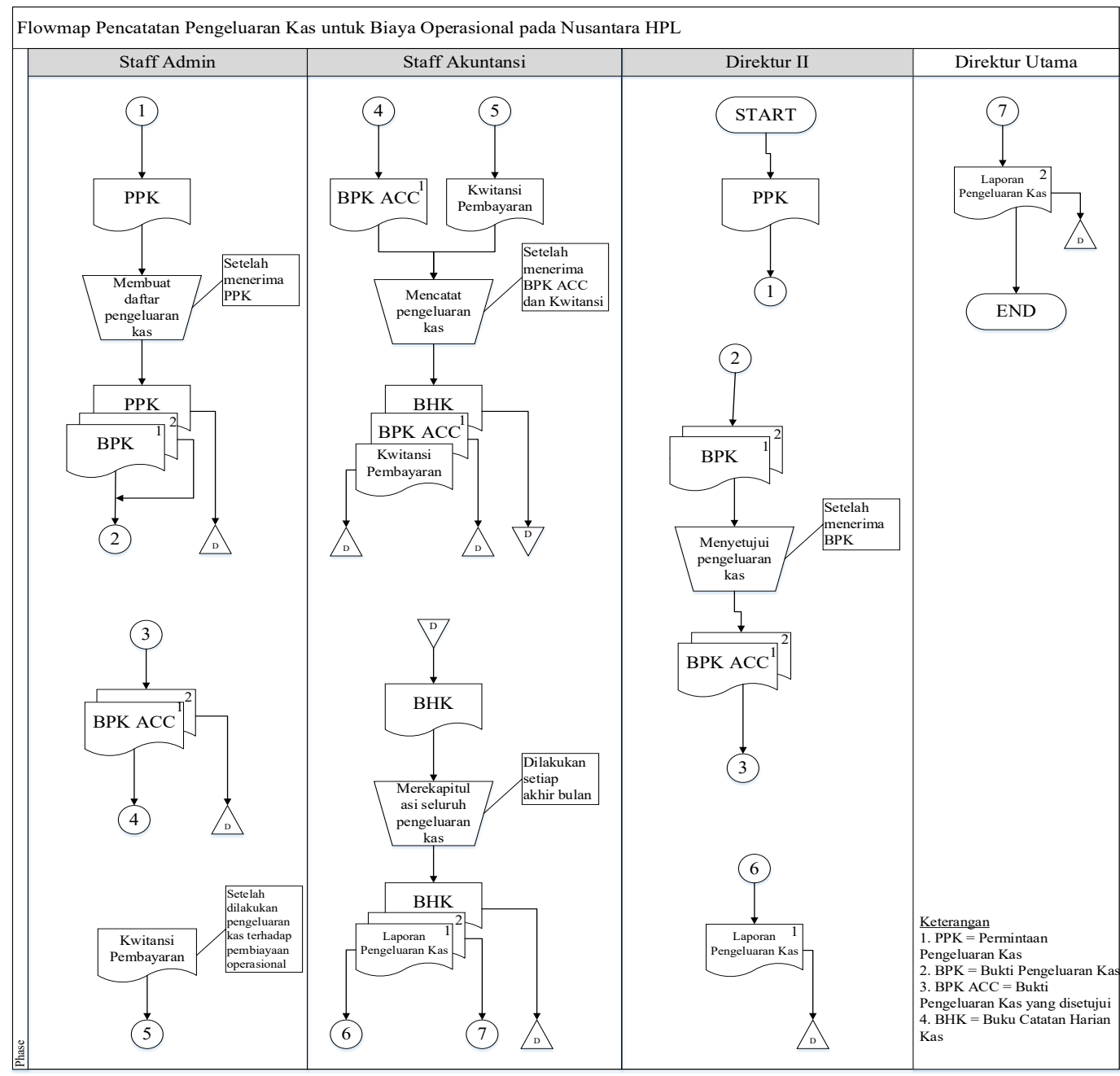

Gambar 3: Flowmap Sistem Berjalan Pencatatan Pengeluaran Kas Biaya Operasional 


\subsection{Uraian Hasil Analisi}

Berdasarkan analisi yang dilakukan dapat dapat diusulkan beberapa perbaikan dari proses bisnis pencatatan pengeluaran kas yaitu dengan memkomputerisasi aktivitas pencatatan data PPK sehingga mempermudah dalam pembuatan bukti pengeluaran kas (BPK) yang akan dilaporkan kepada Direktur II.

Kemudian mengkomputerisasi proses bisnis pencarian data pengeluaran kas, dengan tujuan untuk memudahkan Direktur II melakukan pengecekan bukti pengeluaran kas dengan cara mecari pada database pengeluaran kas kemudian mencari berdsarkan no BPK yang diterima kemudian merubah status approve jika BPK yang diterima sesuai dengan nilai pengeluaran kas yang terjadi.

Usulan berikutnya mengkomputerisasi proses bisnis pembuatan detail pengeluaran kas oleh bagian akuntansi, dengan tujuan memudahkan dan mempercepat bagian akuntansi dalam menangani transaksi serta melakukan rekapitulasi, sehingga pembuatan laporan dapat dilakukan tepat waktu saat dibutuhkan oleh Direktur utama dan Direktur II. Untuk lebih jelasnya akan dijabarkan proses bisnis yang diusulkan dan digambarkan flowmap system usulan.

\subsection{Uraian Proses Bisnis Yang Di Usulkan}

1. Staff Admin akan menerima Permintaan Pengeluaran Kas (PPK) dari Direktur II lalu Staff Admin akan memasukan data PPK tersebut kedalam database dan akan membuat rincian jumlah kas yang harus dikeluarkan, rincian ini disebut Bukti Pengeluaran Kas (BPK) yang selanjutnya akan dicetak sebanyak 1 (satu) lembar dan akan diserahkan kepada Direktur II sebagai permintaan persetujuan untuk mengeluarkan uang dalam rangka melakukan pembayaran terhadap pembiayaanpembiayaan yang harus dilakukan sedangkan PPK yang diterima akan diarsipkan oleh Staff Admin.

2. Setelah Bukti Pengeluaran Kas (BPK) diterima oleh Direktur II maka selanjutnya Direktur akan menandatangani dokumen BPK tersebut lalu mencari data BPK pada Database berdasarkan Nomor BPK yang tertera pada dokumen BPK yang diterima tersebut untuk memperbaharui status BPK menjadi "Approve" pada Database. Dokumen BPK yang telah ditandatangani akan diserahkan kembali kepada Staff Admin. 
3. Staff Admin akan menerima Bukti Pengeluaran Kas (BPK) yang telah disetujui lalu Staf Admin akan mencari data BPK pada Database berdasarkan nomor BPK dan akan memperbaharui data BPK dengan menambah keterangan nama pemakai uang kas atau dengan kata lain pihak atau orang yang menerima uang yang diberikan tanggung jawab dalam pembayaran pembiayaan serta jenis pengeluarannya. Selanjutnya setelah data berhasil diperbaharui maka akan dicetak dan akan diarsipkan terlebih dahulu, lalu Staff Admin akan mengeluarkan uang baik secara tunai maupun transfer bank sejumlah yang tertera pada BPK yang telah disetujui tersebut.

4. Setelah dilakukan pembayaran, Staff Admin akan menerima kwitansi sebagai bukti telah dilakukannya proses pembayaran lalu kwitansi tersebut akan segera diserahkan kepada Staff Akuntansi beserta dengan 1 (satu) lembar Detail Pengeluaran Kas (DPK).

5. Staff Akuntansi akan menerima kwitansi dan Detail Pengeluaran Kas (DPK) yang diserahkan oleh Staff Admin, selanjutnya Staff Akuntansi akan memasukkan data transaksi pengeluaran kas tersebut kedalam database berdasarkan kedua dokumen tersebut dan DPK serta kwitansi tersebut akan diarsipkan.

6. Pada akhir bulan, Staff Akuntansi akan mencetak laporan rekapitulasi pengeluaran kas yang terjadi pada suatu periode tertentu dengan cara memasukkan periode yang akan dicetak pada form yang tersedia pada aplikasi selanjutnya laporan akan diserahkan kepada Direktur Utama dan Direktur II.

Berikut ini pemetaan dari sistem yang diusulkan dengan menggunakan flowmap sistem usulan. 


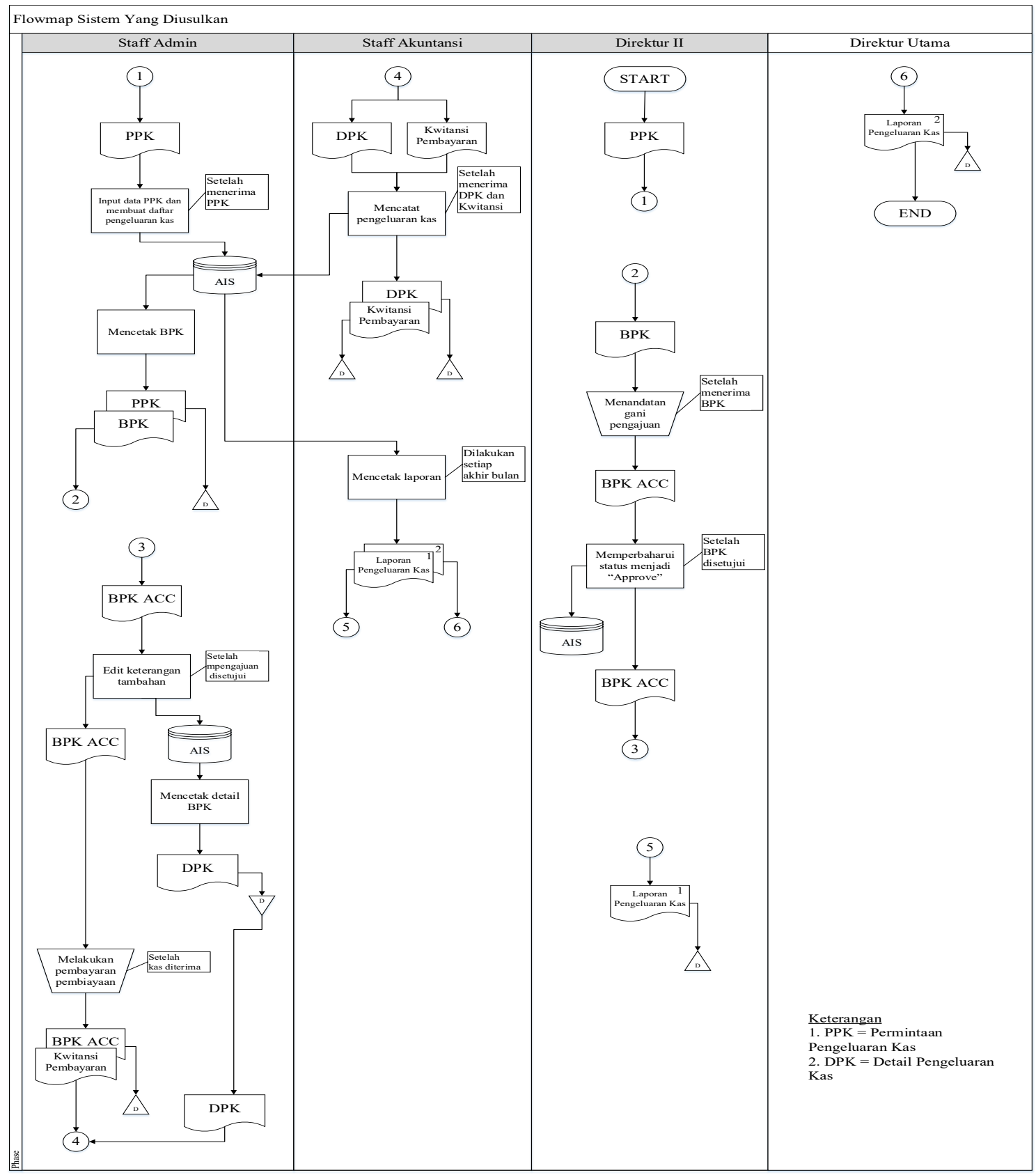

Gambar 4: Flowmap Sistem Usulan Pencatatan Pengeluaran Kas Biaya Operasional

\subsection{Desain Fungsional sistem yang diusulkan}

Pada tahapan ini ditentukan desain fungsionalitas sistem dari aplikasi yang bangun, Perancangan use case memberikan gambaran secara umum interaksi langsung antara user dengan aplikasi. Serta menggambarkan user yang terlibat dalam suatu sistem informasi. 


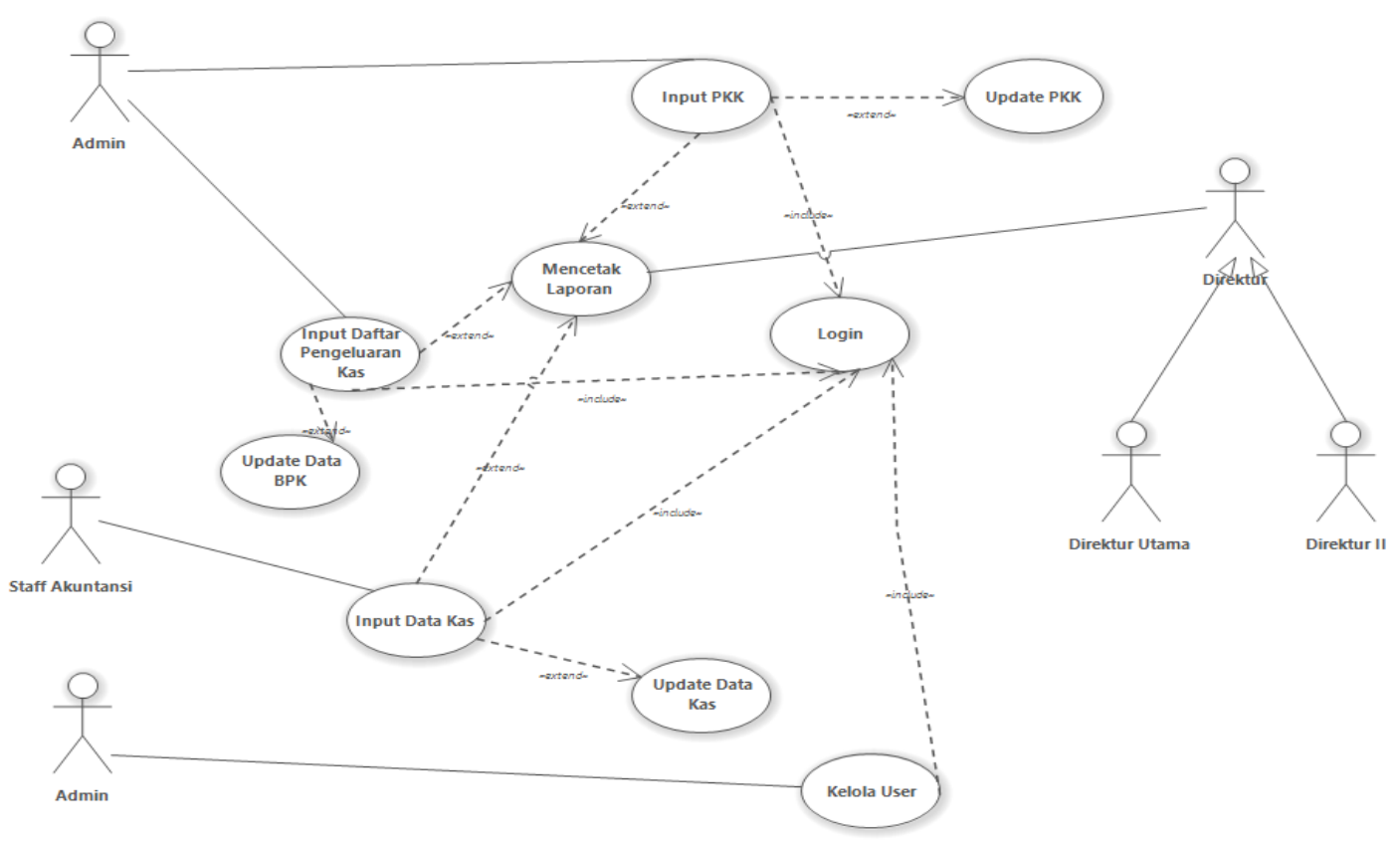

Gambar 5: Usecase Sistem Pencatatan Pengeluaran Kas Biaya Operasional

\subsection{Rancangan Class Diagram Service}

Rancangan class diagram dibuat dengan tujuan untuk memperoleh gambaran mengenai atribut-atribut pada system yang akan dibangun.

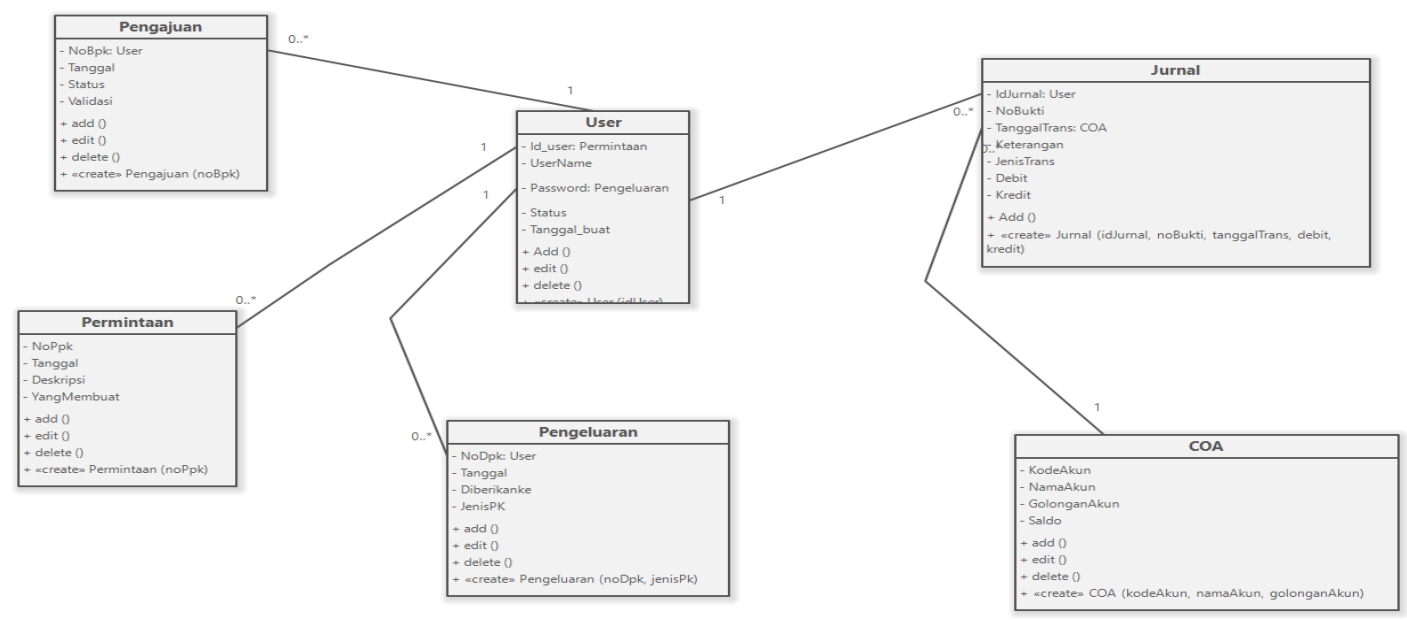

Gambar 6: Class Diagram Sistem Pencatatan Pengeluaran Kas Biaya Operasional

\subsection{Implementasi}

Dalam membangun dan mengimplementasikan aplikasi yang diusulkan terdapat beberapa kebutuhan sistem yang digunakan dengan rincian sebagai berikut: 


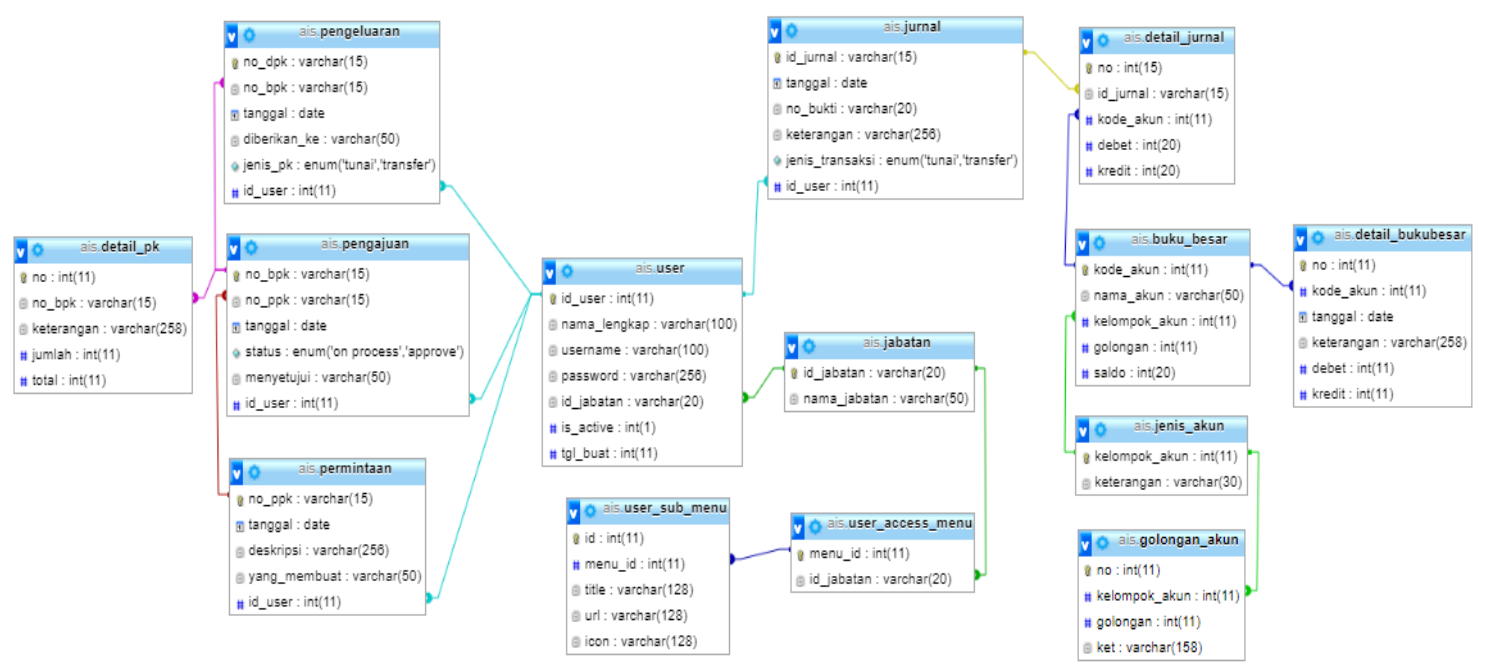

Gambar 7: Rancangan Database Sistem Infomasi Pencatatan Pengeluaran Kas Biaya Operasional

Adapun spesifikasi perangkat keras dan perangkat lunak yang digunakan dalam mengimplementasikan aplikasi sebagai berikut :

Tabel 1. Spesifikasi Hardware dan Software Sisi Server

\begin{tabular}{|c|c|}
\hline Hardware & Software \\
\hline a. Processor Intel Core i3 & a. Sistem operasi windows server 2003 \\
\hline b. RAM minimal $2 \mathrm{~GB}$ & b. Web browser \\
\hline c. Harddisk minimal $320 \mathrm{~GB}$ & c. Webserver Xampp \\
\hline d. Switch & \\
\hline e. Kabel UTP & \\
\hline f. Connector RJ45 & \\
\hline $\begin{array}{l}\text { g. Kartu jaringan (Ethernet Card/LAN } \\
\text { Card) }\end{array}$ & \\
\hline
\end{tabular}

Tabel 2: Spesifikasi Hardware dan Software Sisi Client

\begin{tabular}{|c|c|}
\hline Hardware & Software \\
\hline $\begin{array}{ll}\text { a. Personal computer }(\mathrm{PC}) \\
\text { b. Processor Core } 2 \text { duo } \\
\text { c. RAM minimal } 2 \mathrm{~GB} \\
\text { d. Harddisk minimal } 320 \mathrm{~GB}\end{array}$ & $\begin{array}{l}\text { a. Sistem operasi windows } 7 / 10 \\
\text { b. Web browser }\end{array}$ \\
\hline
\end{tabular}

Adapun implementasi terhadap aplikasi yang diusulkan berdasarkan lingkup dan luas jangkauannya menggunakan jenis jaringan Local Area Network (LAN) dengan skema jaringan client server serta topologi jaringan yang digunakan yaitu topologi star. 
Switch port 8 digunakan sebagai penghubung antara beberapa komponen pembentuk jaringan komputer diantaranya yaitu 1 (satu) server, 3 (tiga) komputer client dan 1 (satu) printer. Server berfungsi untuk memberikan fasilitas kepada beberapa komputer client. Berikut beberapa tugas server sebagai Database Management Systems (DBMS), yaitu:

1. Menyediakan database atau file yang dapat digunakan bersama-sama oleh komputer client

2. Mengatur lalu lintas transfer data atau file yang diminta oleh komputer client

3. Melayani permintaan komputer client untuk menggunakan database atau file

4. Menyimpan data atau file yang dikirim oleh komputer client

5. Mengatur hak akses data atau file

Tiga komputer client memiliki hak akses terhadap database yang berbeda, diantaranya:

1. Komputer client 1 yang digunakan oleh Direktur memiliki hak akses terhadap table User dengan jenis hak akses insert, select, dan delete serta hak akses terhadap table Pengajuan dengan jenis hak akses select dan update

2. Komputer client 2 yang digunakan oleh Staff Admin memiliki hak akses terhadap table Permintaan, Pengajuan dan Pengeluaran dengan jenis hak akses select dan insert

3. Komputer client 3 yang digunakan oleh Staff Akuntansi memiliki hak akses terhadap table Buku Besar, Jenis Akun, Golongan Akun dan Jurnal dengan jenis hak akses select dan insert.

Semua permintaan dari komputer client akan dikirimkan ke server melalui switch, lalu server akan menerima dan memproses permintaan tersebut. 


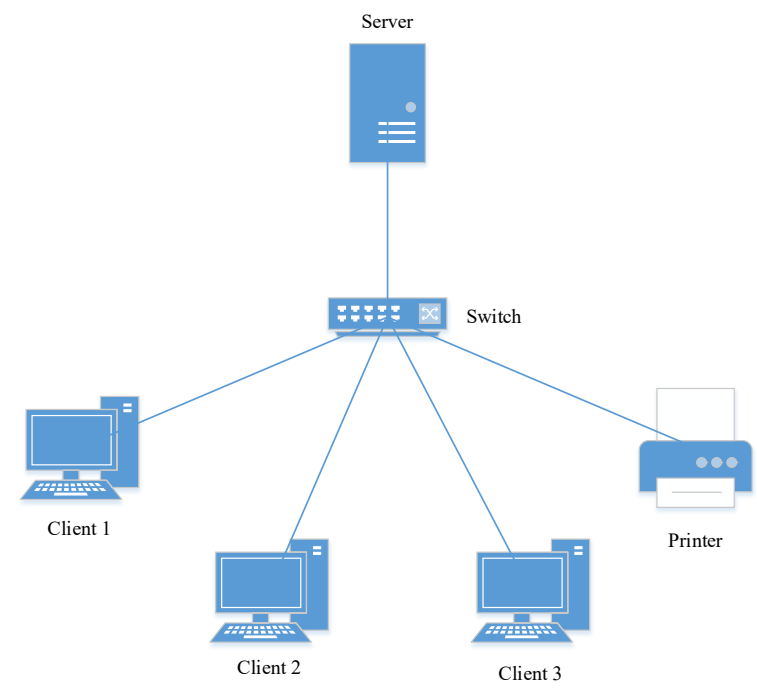

Gambar 8: Skema Struktur Jaringan

Setelah dirancang skema database dari aplikasi yang dibangun kemudian menentukan kebutuhan hardware dan software serta skema jaringan komputer yang dibutuhkan dalam mengimplementasikan aplikasi yang dibangun, maka hal berikutnya yang perlu diimplementasikan adalah antar muka dari aplikasi yang akan digunakan oleh user

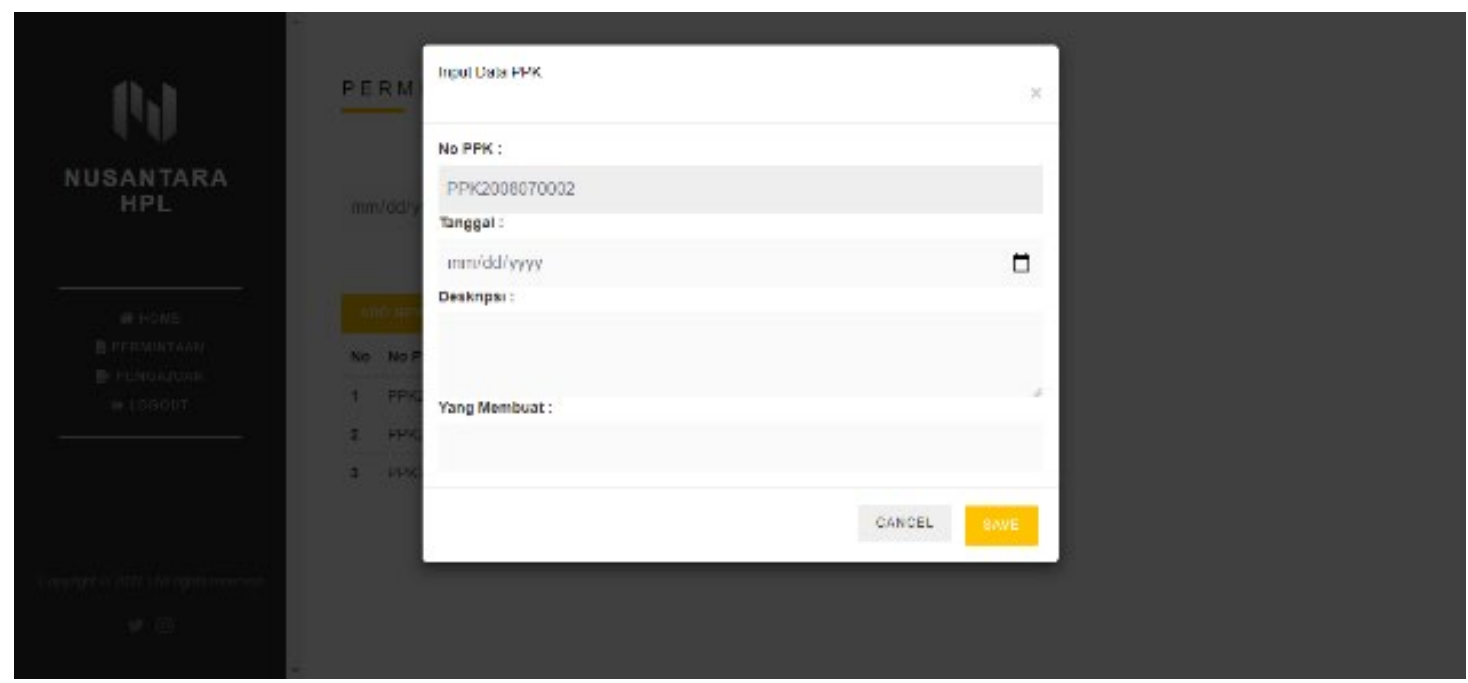

Gambar 9: Halaman form input data Permintaan Pengeluaran Kas (PPK)

Halaman permintaan tersebut untuk memasukkan data permintaan pengeluaran kas berdasarkan perintah Direktur. 


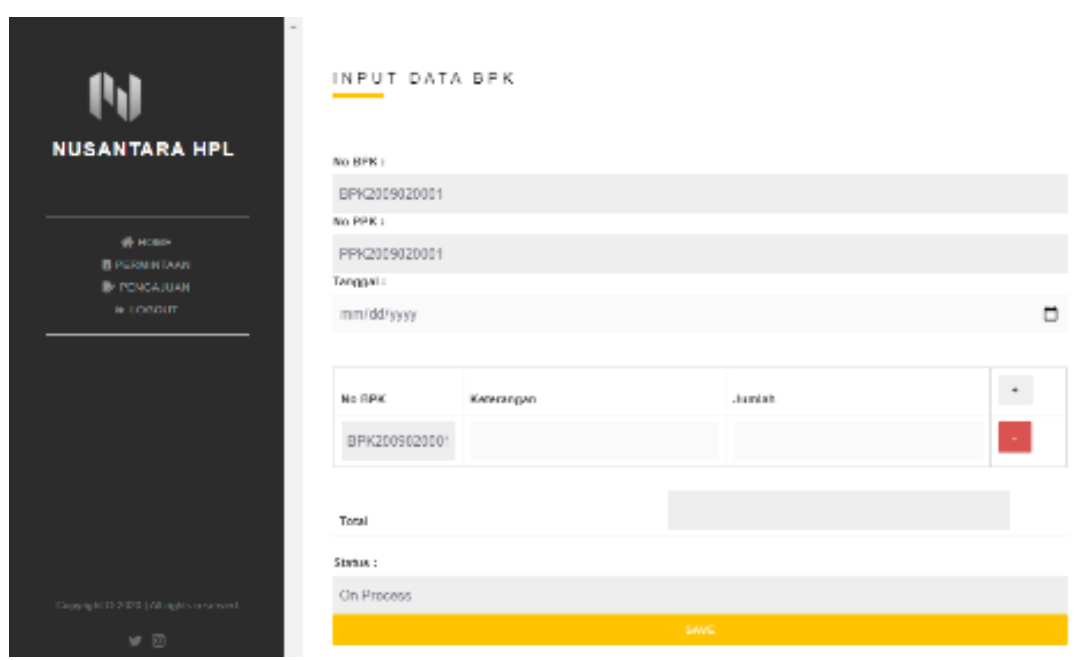

Gambar 10: Halaman form input data Bukti Pengeluaran Kas (BPK)

Halaman Bukti pengeluaran kas ini di isi oleh staff admin untuk menambah keterangan nama pemakai uang kas atau dengan kata lain pihak atau orang yang menerima uang yang diberikan tanggung jawab dalam pembayaran pembiayaan serta jenis pengeluarannya

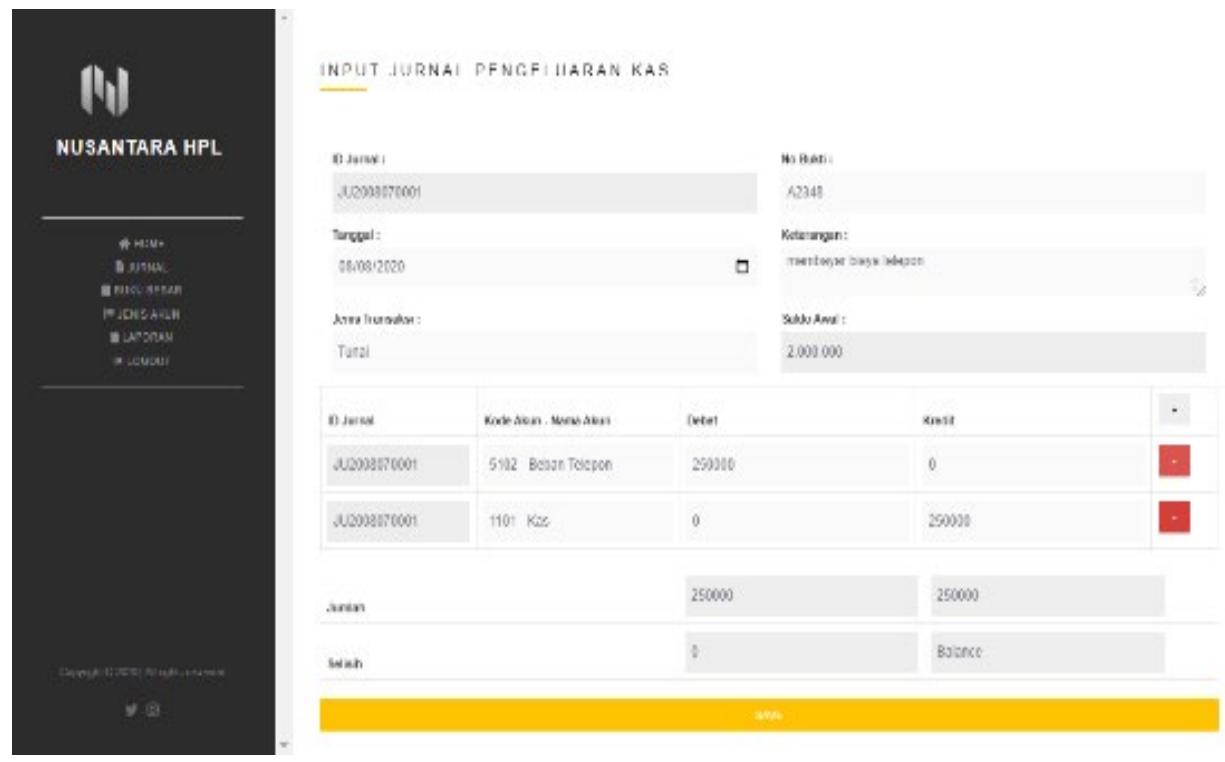

Gambar 11: Halaman Form Input Jurnal Pengeluaran Kas

Halaman ini dibuat oleh staff akuntansi untuk mencatat jurnal dari pengeluaran kas yang terjadi pada periode transaksi tertentu, sehingga dapat di lihat saldo kas yang masih tersedia. 


\section{SIMPULAN DAN SARAN}

\subsection{Kesimpulan}

1. Aplikasi pencatatan pengeluaran kas dapat melakukan kegiatan perhitungan rekapitulasi pengeluaran kas yang terjadi secara terkomputerisasi sehingga pengguna tidak perlu melakukan perhitungan secara manual, sistem akan melakukan perhitungan secara otomatis sehingga pengguna dapat mendapatkan hasil perhitungan rekapitulasi pengeluaran kas dengan mudah dan tepat.

2. Aplikasi pencatatan pengeluaran kas dapat menyajikan data yang dibutuhkan pengguna dengan cepat dan mudah. Pengguna dapat mencari data yang dibutuhkannya dengan cara memasukkan index pencarian pada aplikasi tersebut.

3. Pembuatan laporan pada aplikasi pencatatan pengeluaran kas ini dapat dengan mudah didapat karena pengolahan datanya sudah dilakukan oleh sistem seperti proses perhitungan rekapitulasi pengeluaran kas yang sudah di otomatisasi serta format laporannya sudah tersedia sehingga pengguna dapat langsung mendapatkannya.

\subsection{Saran}

1. Untuk pengembangan lebih lanjut terhadap aplikasi pencatatan pengeluaran kas ini dapat ditambahkan proses pencatatan penerimaan kas sehingga dapat memenuhi kebutuhan perusahaan dalam memperoleh informasi terkait cash flow yang terjadi.

2. Rancangan tampilan antar muka dari notifikasi pesan error jika terjadi kesalahan pada saat validasi input data dapat dikembangkan lebih menarik lagi dengan membuatnya menjadi pop up message.

\section{DAFTAR PUSTAKA}

Cahyati, Y., \& Murti, H. (2018). Sistem E-Surat Pada Government Resource Management System Provinsi Jawa Tengah Berbasis Framework Codeigniter. Universitas Stikubank, 978-979.

Muria, G. (2018). Pengaruh Pendapatan dan Biaya Operasional terhadap Laba Bersih (studi kasus pada Perusahaan Manufaktur Sektor Industri Dasar dan Kimia yang terdaftar di BEI periode 2012-2016). Eqien: Jurnal Ekonomi Dan Bisnis, 5(1), 1933. https://doi.org/10.34308/eqien.v5i1.11

Ningroom, F. K., Husaini, A., \& Azizah, D. F. (2013). EVALUASI SISTEM AKUNTANSI PEMBELIAN DAN PENGELUARAN KAS UNTUK 
MENDUKUNG PENGENDALIAN INTERN [Studi Pada PT. INKA (Persero) Madiun. Jurnal Administrasi Bisnis (JAB), 6(1), 1-8. https://doi.org/10.2466/pr0.1973.33.1.63

Supono, \& Putratama, V. (2016). Pemrograman Web Dengan Menggunakan PHP dan Framework Codeigniter. Deepublish.

Wisesa, I. W. B., Zukhri1, A., \& Suwena, K. R. (2014). Pengaruh Volume Penjualan Mente dan Biaya Operasional Terhadap Laba Bersih Pada UD . Agung Esha Karangasem Tahun 2013. Jurnal Pendidikan Ekonomi Undiksha, 4(1), 1-12. https://ejournal.undiksha.ac.id/index.php/JJPE/article/view/3293 